\title{
Portuguese Exports and FDI: Observations From the Firms’ Perspective
}

\author{
Joaquim Ramos Silva \\ ISEG, Technical University of Lisbon, Lisbon, Portugal \\ Carina Costa Simões \\ Luso-Brazilian Chamber of Commerce, Lisbon, Portugal
}

\begin{abstract}
The paper starts with an overview of the persistent external fragilities of the Portuguese economy and given these circumstances, our aim is to analyze, by means of an inquiry, the Portuguese firms that export and invest abroad, in order to establish their main motives for internationalization, the barriers that they encounter in this process, the organizations which they turn to when looking for support, and the relevance of the existing supporting services. It must be stressed that, within the Portuguese context, studies based on the perspectives of internationalized firms are scarce. In addition, the inquiry's findings enable us not only to know the firms' views in those aspects but also the size of respondents firms (220) and their location. As a result of the research, the adequate management of information through operational networks appears as a central issue for the improvement of the internationalization process of firms. Later, it is considered that the main governmental programs and measures during the past two decades that set the institutional framework underpinning the exporting and investing activities of Portuguese firms, which permits a consideration of the interaction between public and private entities; the institutional frameworks of the 1990s and the first decade of the 21st century are particularly compared. In the light of the empirical findings and the analysis of governmental measures and programs, the study concludes with policy recommendations and draws some lines for further research.
\end{abstract}

Keywords: exports, foreign direct investment, inquiry to firms, samples and statistical analysis, Portuguese economy, external economic policies, internationalization strategies

\section{Introduction}

In the last decades, the Portuguese economy has been broadly characterized by a very vulnerable position as far as its integration into the world economy is concerned (Silva, 2008). It has suffered from chronic high external imbalances, a systematic lack of competitiveness and loss of market share in the main trading partners (Amaral, 2006). It has not often been successful in attempting to enter new markets and neither is it an attractive country for inward foreign direct investment (Silva, 2006; Simões \& Cartaxo, 2011). Moreover, the situation concerning

\footnotetext{
Joaquim Ramos Silva, Ph.D., Associate Professor, SOCIUS-FCT Research Center, Department of Economics, School of Economics and Management, ISEG, Technical University of Lisbon.

Carina Costa Simões, Master in International Economics and European Studies, Luso-Brazilian Chamber of Commerce.

Correspondence concerning this article should be addressed to Joaquim Ramos Silva, ISEG/UTL, Rua Miguel Lúpi, 20, 1249-078 Lisbon, Portugal. E-mail: jrsilva@iseg.utl.pt.
} 
the current account deficit has been particularly serious in the first decade of the 21th century (for example, $-9 \%$ of GDP on average between 2002-2008; Giavazzi, 2010), and the international and domestic crises of 2009-2010 triggered increasing difficulties in satisfying the need for external borrowing, whether public or private. This led to the government's request to the EU-IMF, the former including the European Commission and European Central Bank, for a financial support package in April 2011, the third of this type since 1974. Severely affected by the European sovereign debt crisis, a bailout of 78 billion Euros for the Portuguese economy was agreed in May 2011, and signed by the three main political parties. Later, in the national elections of June 5, 2011, the incumbent government was comprehensively defeated. However, differently from the two previous bailouts of 1978 and 1983, the country is now member of a monetary union, hence the overcoming of the crisis is much more complex and less under the control of Portuguese authorities. The Portuguese crisis has several fundamental causes (Andrade \& Duarte, 2011), but the large, multifaceted and prolonged external fragilities of the economy are obviously one of the most salient features.

Nevertheless, as a small European economy, Portugal should have long since perceived a vital interest in a well-designed and structured internationalization strategy within a suitable environment and, in a way, her chronic, profound weaknesses in this respect are perhaps surprising to the outsider. There are a few research strands to explore on this issue. It was maintained in earlier works that the Portuguese economy is not at all as small and open an economy as it should be, and it still tends to behave as if it were "relatively large and closed" to the rest of the world (Silva, 1999, 2002, pp. 44-46; 2008, pp. 14-15), which naturally leads to inappropriate macroeconomic management and to an actual underestimation of the competitiveness dimension. Although much official rhetoric has been pronounced on internationalization, competitiveness, economic diplomacy and similar expressions, particularly in the past decade, it has become largely accepted, if not consensual among professional economists, that Portuguese economic policy throughout the last 25 years or so has contained a systematic bias favorable to the production of non-traded goods and services, and to the detriment of traded goods and services (for example, Bento, 2010). So far, no clear reversal of this bias has been undertaken. In addition, some authors have emphasized other aspects, like the slower pace of upgrading of the Portuguese export structure, and concomitantly, the maintenance of a low content of added value in the exports of goods and services, when compared, for example, with groups of Asian countries which have grown at a much faster pace from this perspective (Dias, 2006). Similarly, while the ability to respond quickly to changes in the world economy can be one of the main strengths of a small economy, Portugal seems to lack such ability. In spite of their great relevance, these and other similar arguments will not be specifically examined in the present study.

In this paper, the Portuguese external problem will be analyzed from the viewpoint of exporting and investing firms, which undoubtedly have a key role in any internationalization process. Indeed, on the Portuguese external problem, there is a clear dominance of macroeconomic approaches, and a scarcity of studies based on the experience and views of firms (GEPE, 2001). Our intention is to change this deep-rooted intellectual environment. In this sense, it must be emphasized that, notwithstanding many caveats, Bergeijk (2009, p. 74) went so far as to affirm explicitly that:

Firms that export, import, invest or have a head office in another country are more productive, larger, do more research and development, have a higher survival rate and pay better wages than firms that are only connected to local markets. 
Such a conclusion has implications for public policies, not only in Portugal, but also in other countries. In our case, since the 1980s, with EU support through structural funds, governments have approved policies and claimed to have implemented measures designed with the aim of overcoming the basic drawbacks of the Portuguese external sector, and in order to facilitate the internationalization process of firms. However, in a manner very much representative of the insufficiencies of economic policies effectively pursued by successive governments, woefully scant attention was paid, for example, to the Report of Michael Porter (1994), specifically framed to improve the international competitiveness of the Portuguese economy and firms through the logic of clusters within the perspective of deepening European integration. Later, successive governments attempted to reorganize services associated with internationalization, targeting more focused policy objectives; so far, the results have again been poor, ${ }^{1}$ and more in-depth and consistent policies are still necessary.

Certainly, it will not be provided in the present paper a full explanation of this weak performance and its structural causes, even from the perspective of firms, but there is an endeavor to answer some related questions such as: Are the targets of governmental measures appropriate? Are firms too passive? Why do they have such difficulties in the upgrading of their internationalization activities? Is there any overall strategy instead of a piecemeal approach from both sides (firms and government)? Are appropriate knowledge services available to firms (provided by public, semi-public or private organizations such as the AICEP, the chambers of commerce, and employers associations) in this age of information? What are the "costs of the context"? These are some of the questions to be answered in our study, on the basis of an inquiry that was conducted among 220 respondent firms.

Therefore, following this introduction, in the next section, it will be presented the sample and the methodology that were adopted, as well as the main findings of the inquiry to firms, considering separately exports and foreign direct investment. By doing so, and taking into account the context of the knowledge economy, it will use the main theoretical tools of relevant literature on firms' internationalization and services geared towards its promotion. In the third section, the main measures and frameworks under which Portuguese firms have internationalized since the 1990s will be described and commented. In the final section, some results of the present analyses are discussed, and some policy recommendations appropriate to the Portuguese case will be put forward, particularly regarding the pursuit of the research on firms' internationalization.

\section{The Inquiry to Firms and Its Main Findings}

In this section, firstly, it is presented our methodology as well as the sample of firms that were studied. In the inquiry, it emphasized the motives that led Portuguese firms to internationalization, the main barriers that they encountered during the process, and the organizations that were contacted for assistance, together with their evaluation of available supports of different types according to their relevance. For statistical purposes, although the inquiry was conducted in 2009-2010, the year 2007 was selected as the basis for responses to the questionnaire, in order to avoid the effects of the international crisis that could bias the analysis. Next, the main

\footnotetext{
${ }^{1}$ If the fall in international trade flows in 2009 and its immediate effects are abstracted, it is true that there was a positive evolution of the Portuguese exports of goods and services from the middle of the previous decade, including 2010 and 2011. However, it is too early to claim a change towards a sustained, competitive movement of exports, and it is still less certain that the structural fragilities of the Portuguese economy, as they were just described, have been addressed. Later on, the subject will be further analyzed.
} 
empirical findings of our inquiry concerning not only exports but also outward FDI are shown, and whenever possible, the responses of the two groups of firms are compared.

\section{The Initial Sample and Respondent Firms}

The initial sample of the study was composed of 4,425 enterprises to which the questionnaire was submitted. In the following step, once responses were obtained, 220 questionnaires of enterprises with international activity (exports, foreign direct investment, or both) were validated, and these two samples, organized according to economic activity, are shown in Table 1. In the initial sample, there was a representation of all districts (main regional administrative division in Portugal at the medium level), as well as from the two autonomous regions of Azores and Madeira. With regard to respondent firms, the districts with highest frequency were those of Lisbon and Aveiro, both with $16.1 \%$, followed by Porto with $14.2 \%$, Santarém $11.5 \%$, and Braga $11.1 \%$. All of the remaining districts and both autonomous regions had figures below $10 \%$. The concentration on the Portuguese coastal districts north of Lisbon is not surprising and is in conformity with other inquiries that have been recently conducted (Franco, Haase, Magrinho, \& Silva, 2011, p. 274). However, it is interesting to note that some districts of Central Portugal (Coimbra, Guarda, and Viseu) evidenced a higher rate of respondent firms in relation to the distribution of the initial sample.

If the type of economic activity is considered (18 types according to NACE codes), it can be observed that the most represented sectors among respondent firms were manufacturing with $63.59 \%$, followed by the combined category of wholesale and retail trade, and repair of motor vehicles and motorcycles with $22.58 \%$. The remaining items were all below 5\%. With a few discrepancies (construction), the results are similar in both samples. Prima facie, such a high weight of only two sectors presents a strong case for their discrimination in further studies on the subject. All figures are shown in Table 1 (for other details, see Simões, 2010).

Table 1

Initial Sample and Respondents

\begin{tabular}{|c|c|c|c|c|c|c|c|}
\hline Initial sample & & & & Respondent & & & \\
\hline NACE & $\%$ & District & $\%$ & NACE & $\%$ & District & $\%$ \\
\hline $\begin{array}{l}\text { Agriculture, forestry and } \\
\text { fishing }\end{array}$ & 1.53 & Aveiro & 16.8 & $\begin{array}{l}\text { Agriculture, forestry and } \\
\text { fishing }\end{array}$ & 1.39 & Aveiro & 16.1 \\
\hline Mining and quarrying & 0.81 & Beja & 0.2 & Mining and quarrying & 0 & Beja & 0 \\
\hline Manufacturing & 68.93 & Braga & 13.1 & Manufacturing & 63.59 & Braga & 11.1 \\
\hline $\begin{array}{l}\text { Electricity, gas, steam and air } \\
\text { conditioning supply }\end{array}$ & 0.02 & Bragança & 0.3 & $\begin{array}{l}\text { Electricity, gas, steam and air } \\
\text { conditioning supply }\end{array}$ & 0 & Bragança & 1.8 \\
\hline $\begin{array}{l}\text { Water supply; sewerage; } \\
\text { waste management and } \\
\text { remediation activities }\end{array}$ & 0.45 & $\begin{array}{l}\text { Castelo } \\
\text { Branco }\end{array}$ & 1.4 & $\begin{array}{l}\text { Water supply; sewerage; waste } \\
\text { management and remediation } \\
\text { activities }\end{array}$ & 0.46 & Castelo Branco & 0.9 \\
\hline Construction & 0.75 & Coimbra & 2.8 & Construction & 3.69 & Coimbra & 3.7 \\
\hline $\begin{array}{l}\text { Wholesale and retail trade; } \\
\text { repair of motor vehicles and } \\
\text { motorcycles }\end{array}$ & 24.09 & Évora & 1.2 & $\begin{array}{l}\text { Wholesale and retail trade; } \\
\text { repair of motor vehicles and } \\
\text { motorcycles }\end{array}$ & 22.58 & Évora & 0 \\
\hline Transport and storage & 0.11 & Faro & 1.0 & Transport and storage & 0.46 & Faro & 1.4 \\
\hline $\begin{array}{l}\text { Accommodation and food } \\
\text { service activities }\end{array}$ & 0.05 & Guarda & 0.8 & $\begin{array}{l}\text { Accommodation and food } \\
\text { service activities }\end{array}$ & 0.46 & Guarda & 3.2 \\
\hline $\begin{array}{l}\text { Information } \quad \text { and } \\
\text { communication }\end{array}$ & 1.29 & Leiria & 9.1 & $\begin{array}{l}\text { Information } \\
\text { communication }\end{array}$ & 1.84 & Leiria & 8.8 \\
\hline $\begin{array}{l}\text { Financial and insurance } \\
\text { activities }\end{array}$ & 0.25 & Lisbon & 17.7 & $\begin{array}{l}\text { Financial and } \\
\text { activities }\end{array}$ & 1.39 & Lisbon & 16.1 \\
\hline
\end{tabular}


(Table 1 continued)

\begin{tabular}{|c|c|c|c|c|c|c|c|}
\hline Initial sample & & & & Respondent & & & \\
\hline NACE & $\%$ & District & $\%$ & NACE & $\%$ & District & $\%$ \\
\hline Real estate activities & 0.18 & Portalegre & 0.5 & Real estate activities & 0.46 & Portalegre & 0 \\
\hline $\begin{array}{l}\text { Professional, scientific and } \\
\text { technical activities }\end{array}$ & 0.95 & Porto & 23.3 & $\begin{array}{l}\text { Professional, scientific and } \\
\text { technical activities }\end{array}$ & 2.30 & Porto & 14.2 \\
\hline $\begin{array}{l}\text { Administrative and support } \\
\text { service activities }\end{array}$ & 0.40 & A.R. Azores & 0.2 & $\begin{array}{l}\text { Administrative and support } \\
\text { service activities }\end{array}$ & 0.46 & A.R. Azores & 0.5 \\
\hline Education & 0.05 & A.R. Madeira & 0.3 & Education & 0.46 & A.R. Madeira & 0.5 \\
\hline $\begin{array}{l}\text { Human health and social } \\
\text { work activities }\end{array}$ & 0.02 & Santarém & 3.8 & $\begin{array}{l}\text { Human health and social work } \\
\text { activities }\end{array}$ & 0.46 & Santarém & 11.5 \\
\hline $\begin{array}{l}\text { Arts, entertainment and } \\
\text { recreation }\end{array}$ & 0.07 & Setúbal & 2.9 & $\begin{array}{l}\text { Arts, entertainment and } \\
\text { recreation }\end{array}$ & 0 & Setúbal & 5.1 \\
\hline \multirow[t]{3}{*}{ Other services activities } & 0.05 & V. do Castelo & 1.6 & Other services activities & 0 & V. do Castelo & 0 \\
\hline & & Vila Real & 0.8 & & & Vila Real & 0 \\
\hline & & Viseu & 2.2 & & & Viseu & 5.1 \\
\hline Total & 100 & Total & 100 & Total & 100 & Total & 100 \\
\hline
\end{tabular}

\section{Exports}

Firstly, with regard to the analysis of respondent firms whose internationalization is based on exports, there were a total of 186, broken down as follows: $19.4 \%$ had fewer than 10 employees, $46.5 \%$ had between 10 and 49 employees, and $34.4 \%$ had 50 or more employees. Figure 1 shows the results in percentages, also with the accurate number of firms $(F)$ for each case. Although the classification type of the European Union was not strictly followed, ${ }^{2}$ the first case corresponds to micro-enterprises, while the second category is mainly representative of small enterprises, and the third mostly of small and medium-sized enterprises (SMEs), even though some larger firms may have responded and were placed in this latter category.

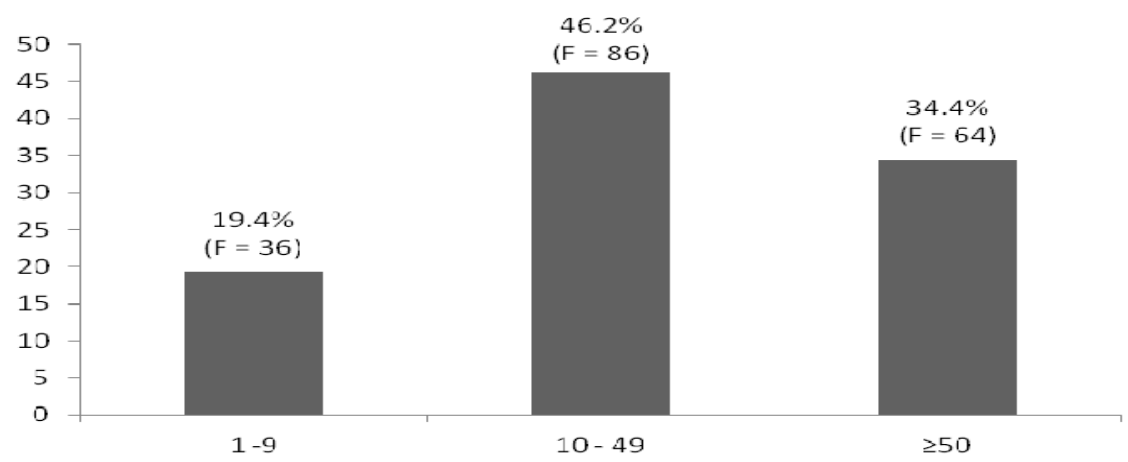

Figure 1. Respondent firms by number of employees.

It must be pointed out that, due to the high proportion of small and medium-sized (SMEs) firms in the Portuguese industrial structure, ${ }^{3}$ the responses obtained at this level are basically representative of exporting SMEs. In addition, it must be highlighted that micro-enterprises represent almost one fifth of the respondents,

2 According to the EU criteria, the classification in vigor is: one to nine employees-Micro-enterprise, 10 to 49 employees-Small Enterprises, from 50 to 250 employees-Small and Medium Enterprises.

${ }^{3}$ According to estimates for 2010 provided by the European Commission (2011), SMEs in Portugal represent $99.9 \%$ of the total number of firms (99.8\% in the EU-27). But the importance of SMEs is much more accentuated in employment (80.9\% in Portugal, and $66.9 \%$ in the EU-27), and added value (67.2\% in Portugal, and 58.4\% in the EU-27). As far as large firms are concerned, i.e., those with more than 250 employees, Portugal has only 800 enterprises within a total of 1,000,122 (European Commission, 2011). 
and the micro and small enterprises together reach almost two thirds of the total.

Respecting the main motives behind their internationalization (in responding to this question, there was more than one option), the great majority of firms considered the increase in their market share (83.3\%) as the main reason to internationalize (see Figure 2). Recognition in the domestic market and resource-seeking motives produced close figures, $22.6 \%$ and $19.9 \%$, respectively, although quite distant from the first factor. The firms could also choose other motives, such as the lack of demand and the small size of the national market, as complements to the increase in the market share. The fact that national firms are demanded by foreign counterparts interested in their products also appears as a motive for internationalization, showing some degree of passivity from Portuguese firms regarding the search for new clients and the introduction of their products in external markets. Nonetheless, firms seem to be eager to expand their market share through internationalization.

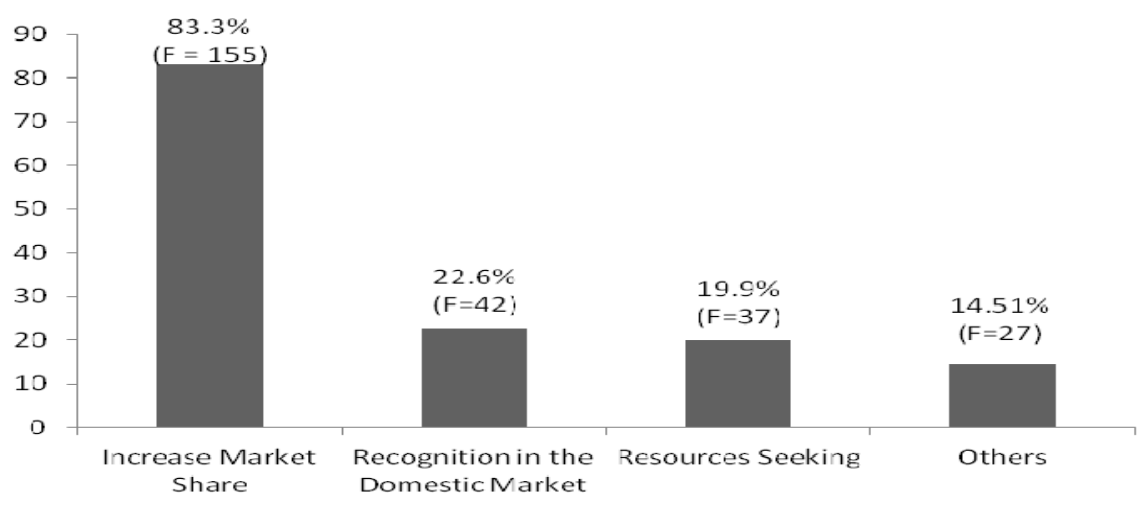

Figure 2. Main motives for internationalization.

As far as the barriers to internationalization are concerned (again, firms could signal more than one option), respondent firms conveyed the lack of incentives as the main obstacle (59.1\%). However, as it will become clear in the following section, governmental measures had been implemented since the 1990s, although it is possible that they were not in tune with the firms' needs, or simply, that firms were unaware of them. This issue will be discussed further in the paper. As shown in Figure 3, respondents also negatively evaluated the existing bureaucracy (48.4\%), certainly a barrier deserving particular attention from governments. In the ranking, the third barrier is the lack of information with 33.3\%, probably caused by its dispersion and the multiplicity of entities involved in promoting support to internationalization. It is likely that existing information is not sufficiently clear and focused on the needs of firms. On the other hand, it must be emphasized that language is not considered as a significant hurdle (only $10.2 \%$ of firms gave an affirmative response). Among the remaining barriers ("others" with 20.96\%), respondent firms specified the lack of financial support and of their own liquidity to invest, competition in the foreign markets, and the lack of free-of-charge commercial information; however, in this heterogeneous item, the lack of qualified human resources was by far the most important barrier indicated by respondents.

In the context of the inquiry, one of our main objectives was to evaluate the importance of the organizations whose raison d'être is to play, directly or indirectly, a role in the internationalization process of Portuguese firms. In the responses (see Figure 4), where firms could choose more than one option, the AICEP (Agency for Investment and Foreign Trade of Portugal) stands out with 59.7\%, showing that the majority of firms had 
contacted this organization with that purpose. Commercial and employers' associations (39.8\%), the IAPMEI (Institute of Support to Small and Medium-Sized Enterprises and Investment) (31.2\%) and the chambers of commerce (30.1\%) were also significantly in demand for their support to internationalization. In our view, in order to rationalize such a process, it would be important to look for synergies between all these organizations, insofar as they often operate quite separately from each other, which increases costs and likely originates mismanagement and conflicts. It must be pointed out that $22.6 \%$ of the firms revealed that they had not sought support from any organization whatsoever. This is a surprising finding, although not completely unexpected, judging by the opinions often expressed by individual firms. Furthermore, in the item "others", respondent firms indicated that they turned to banks in seeking support to internationalization, suggesting that, at least for a certain proportion of Portuguese firms, banks and credit organizations should have a more active role in the process.

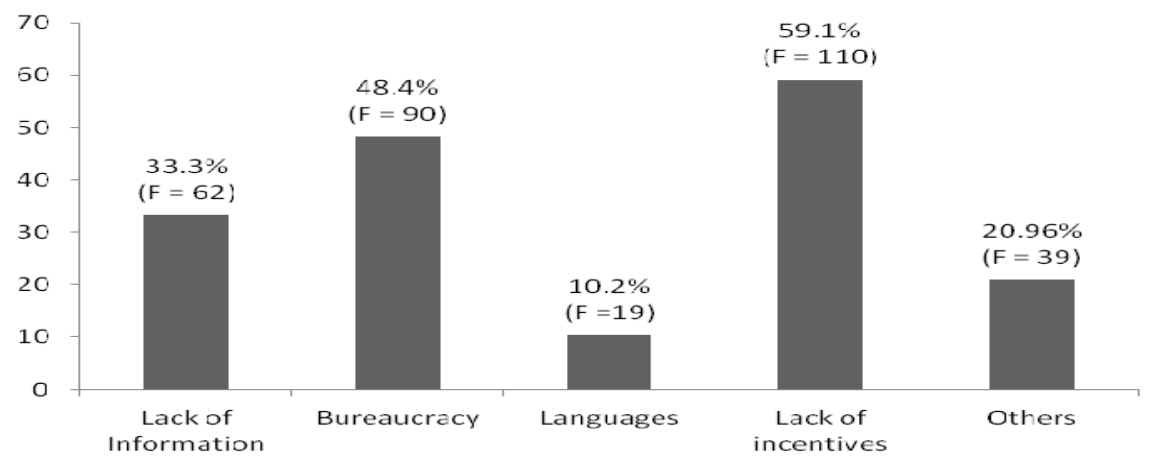

Figure 3. Main barriers to internationalization.

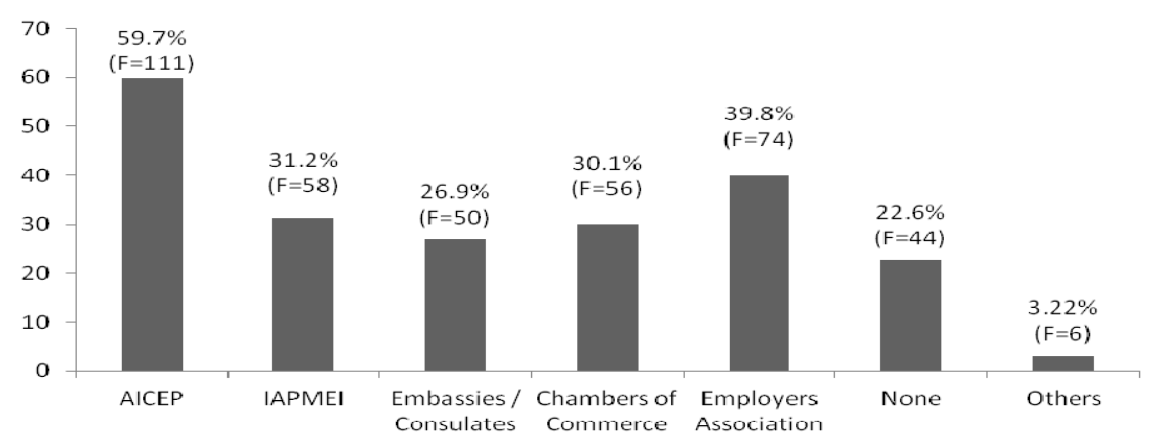

Figure 4. Main organizations contacted as a support of exports.

In the pursuit of our inquiry, it was necessary to know which type of support firms appreciated most (in the responses, more than one option was accepted). Figure 5 shows the results obtained. It emerges that the largest number of respondent firms prioritize the need for information on external markets (67.7\%), followed by information on financial support (54.8\%), and thirdly, on incentive programs (48.4\%). These three items clearly stand out above all the others, showing the deep need for information felt by firms at various levels. This need for information is also apparent in other studies, although Portuguese firms still seem reluctant, compared with those of other countries, to adopt the use of instruments and procedures of competitive intelligence (Franco, Magrinho, \& Silva, 2011). In addition, it is worth noting that of the nine items explicitly considered in this question, all have a significant representation (at least 22\%), revealing that Portuguese exporting firms considered as relevant a rather broad range of support services for their internationalization. 


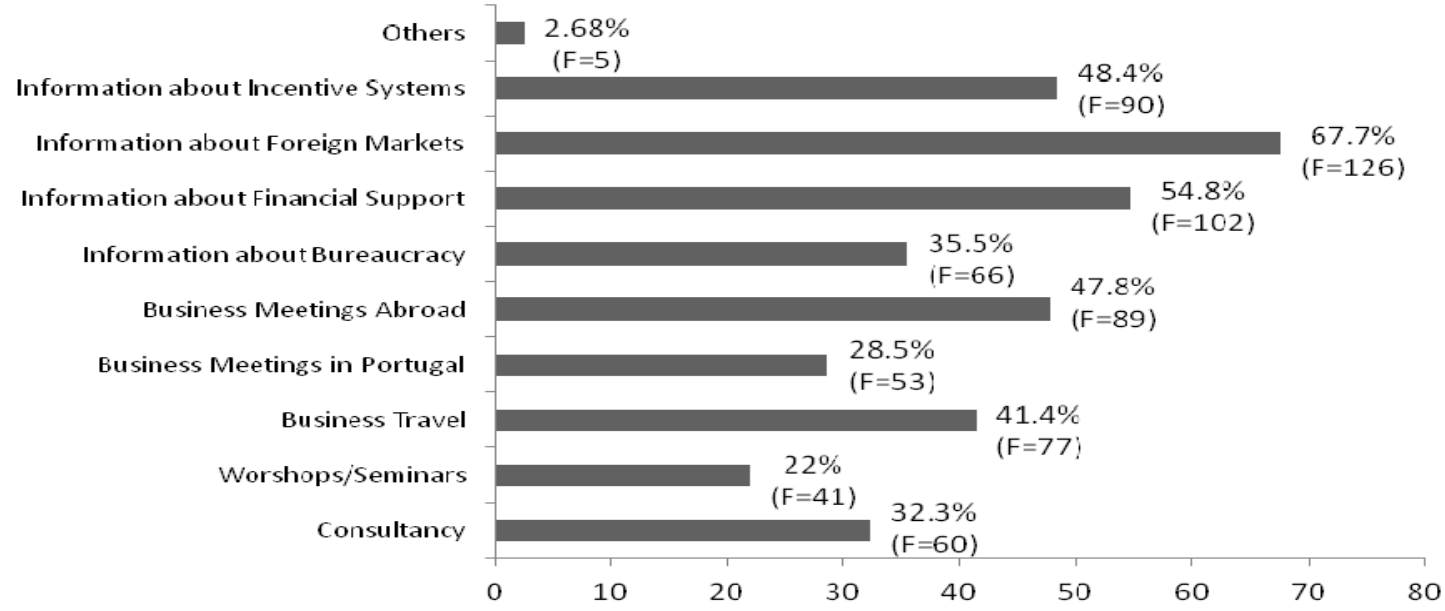

Figure 5. Ranking of supports considered as relevant.

In an overall appreciation of responses conveyed by exporting firms, it may be concluded that the large majority are SMEs that seek, through internationalization, to expand their market share and that the main obstacles to this process, according to their views, are the lack of incentives and bureaucracy. Their responses are much more widely distributed in relation to the key organizations contacted for assistance and to the supports considered as relevant. In the latter case, problems linked to the lack of information clearly stand out.

\section{Foreign Direct Investment}

The analyses of the results regarding firms that invest abroad are also very illustrative. As referred to above, only 34 respondents fell into this category, hence Portuguese firms engaged in exporting seem to be much more numerous than those in foreign investment, which is not surprising considering the belated modern internationalization of the country. Regarding options for each response, the conditions were similar in both cases that were analyzed.

As far as the number of employees is concerned (see Figure 6), there is an apparent difference to the results of exporting firms: relatively larger firms are now much more representative: $64.7 \%$ of respondent firms that invest abroad have 50 employees or more, 23.5\% between 10 and 49, and only $11.8 \%$ are micro-enterprises with less than 10 employees. In the light of these figures, it is interesting to recall the view often expressing that "large firms tend to be more multinational than small firms” (Dunning, 2000, p. 165). Indeed, taking into account the nature of FDI, which is more of a long-term venture, requiring a stronger and deeper involvement and consequently, the need for larger financial capabilities and human resources that many smaller firms cannot afford, it is not surprising that relatively larger firms are now much more in evidence.

With respect to the principal motives for internationalization through foreign investment (see Figure 7), Portuguese firms mainly emphasize the need for increasing their market share (79.4\%) and other relevant motives are resources-seeking (26.5\%) and recognition in the domestic market (23.5\%). If these responses with those of the exporting firms are compared, the most salient difference lies in the higher proportion of the resources-seeking motive among investing firms, which seems quite plausible. It must be taken into account that resource-seeking is considered as one of the main determinants of FDI in the relevant literature (UNCTAD, 1998, p. 91). 


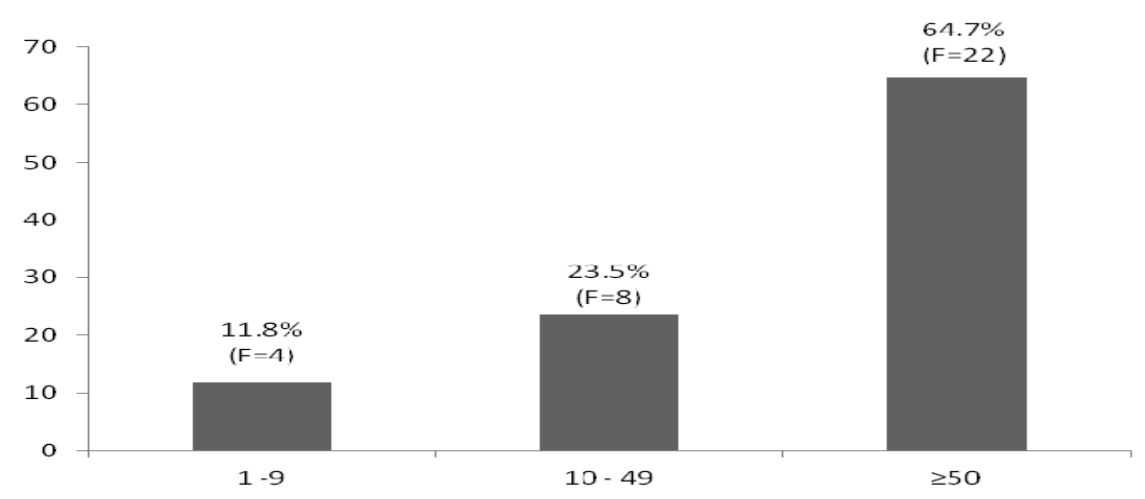

Figure 6. Respondent firms by number of employees (FDI).

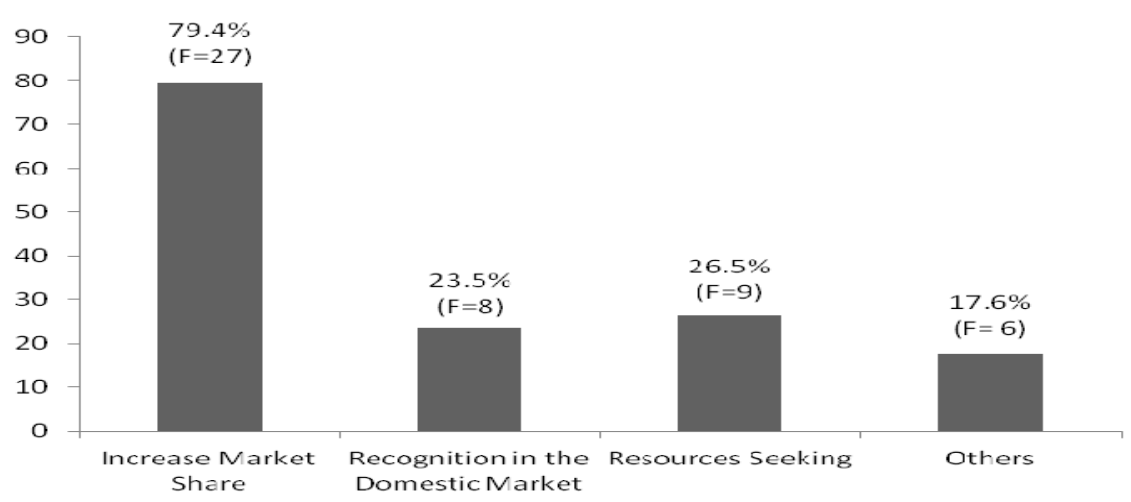

Figure 7. Main motives for internationalization (FDI).

As can be observed in Figure 8, among the main barriers to internationalization as felt by investing firms, bureaucracy clearly stands out with $67.6 \%$, followed by the lack of incentives with $58.8 \%$. This may also be considered quite understandable if it is borne in mind that foreign direct investment takes a longer time and must comply with more formalities than exports (where the lack of incentives, rather than bureaucracy, was considered a more important barrier). Broadly speaking, with more resources than exporting firms, the lack of information as such is less felt as a barrier by investing firms (23.5\%). Other barriers seem negligible, and this is the case of languages (only $11.8 \%$ of respondent firms think of them as an obstacle).

The last two empirical findings that will be analyzed show some similarities in relation to exporting firms, but at the same time, important differences. With regard to organizations contacted for support (see Figure 9), the AICEP again occupies the first place in the ranking with 67.6\%, clearly a higher rate than that for exporting firms. However, not surprisingly, embassies and consulates are now in second place, with $52.9 \%$ of responses, a much higher figure than in the previous case (only $26.9 \%$ for exporting firms). This is probably due to the important role played by the so-called economic diplomacy. Employers' associations and chambers of commerce are also more highly valued in this case. On the contrary, the IAPMEI is less important (23.5\%), while the number of firms reporting that they have not looked for support from any organization is significantly lower (8.8\%). It may be that this number again reflects the lesser weight of micro and small enterprises in this responding sample, given the supposition that larger firms invest abroad on the basis of their own resources and advantages, but, in relation to exporting firms, they also have easier access to qualified information networks, such as the diplomatic corps and others. 


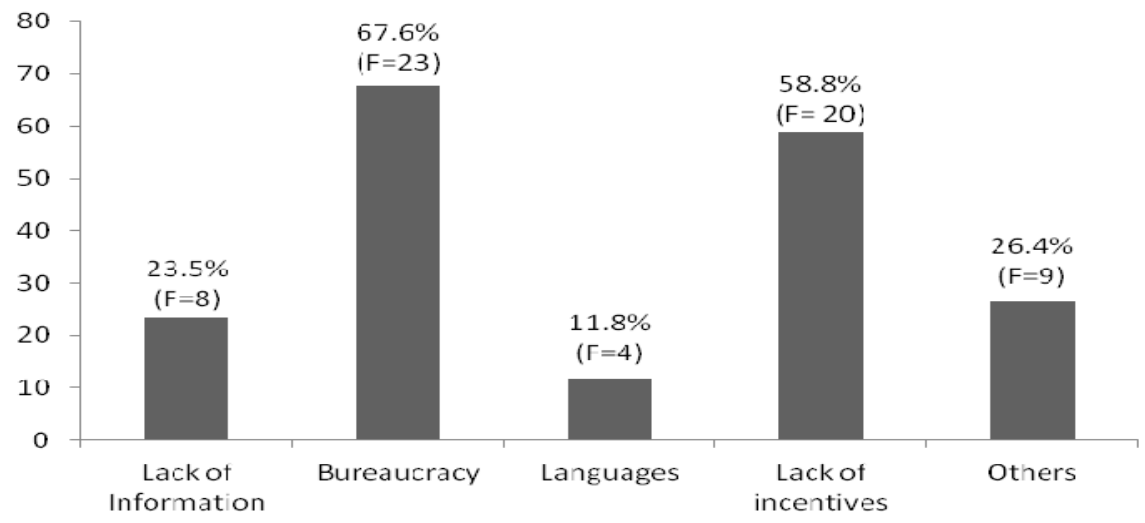

Figure 8. Main barriers to internationalization (FDI).

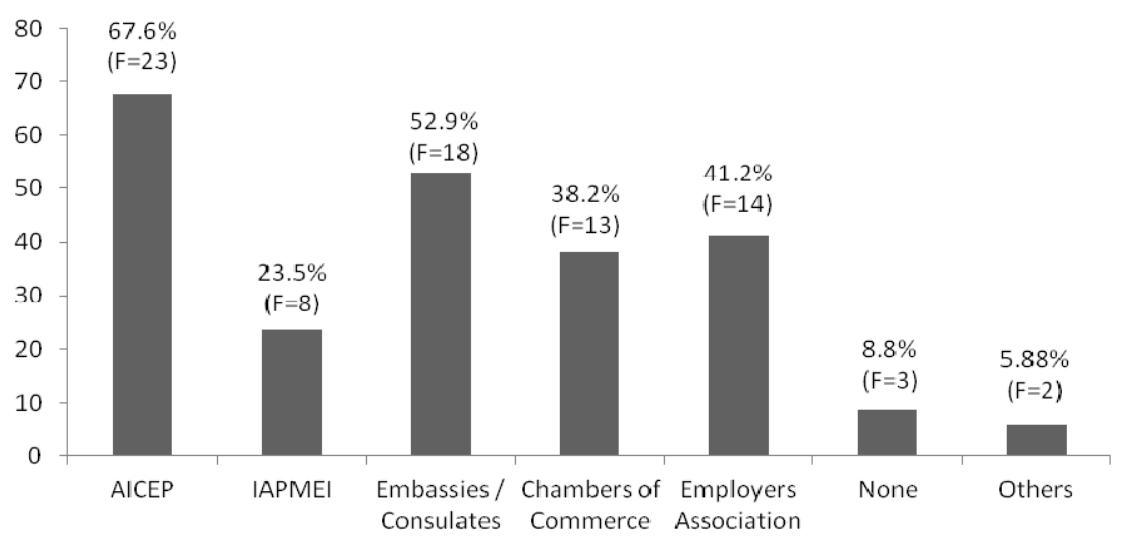

Figure 9. Main organizations contacted for support by investing firms.

With regard to the supports considered as relevant by investing firms, all items linked to information, including business meetings abroad, have now higher rates (see Figure 10). As underlined earlier for exports, problems of information are crucial for internationalization, and investing firms clearly confirm this, with even greater emphasis. Therefore, this is probably one of the domains in which more changes are needed, by promoting measures that truly create a competitive intelligence system that efficiently manages the information provided to Portuguese internationalized firms (Franco, Magrinho, \& Silva, 2011). Again in comparison with exports, workshops and seminars (8.8\%), and business meetings in Portugal (14.7\%) are now much less valued. Business travel (35.3\%) and consultancy (29.4\%) are also not as relevant to these firms, but their decline is not as great as in the two previous items.

Despite the fact that the number of firms investing abroad that responded to our questionnaire was relatively small (only 34), it is possible to draw some conclusions, particularly from a comparative perspective with exporting firms. First, the number of firms with 50 employees and more now represents almost two-thirds of the total, a much higher figure than for exports. Second, the main motive for internationalization-increase in the market share-ranks similarly in both cases (79.4\% and $83.3 \%$, respectively). Perhaps the most important difference at this level lies in the resource-seeking motive, clearly more highly valued by investing firms. Third, as far as the main barriers are concerned, bureaucracy rather than the lack of incentives tops the rankings for investing firms. Fourth, investing firms also seek much more the services of embassies and consulates (in spite of 
maintaining the AICEP as the organization most contacted with assistance). Fifth, in relation to the supports ranked as relevant, both groups of firms strongly value information items, but this is much clearer in the case of firms that invest abroad.

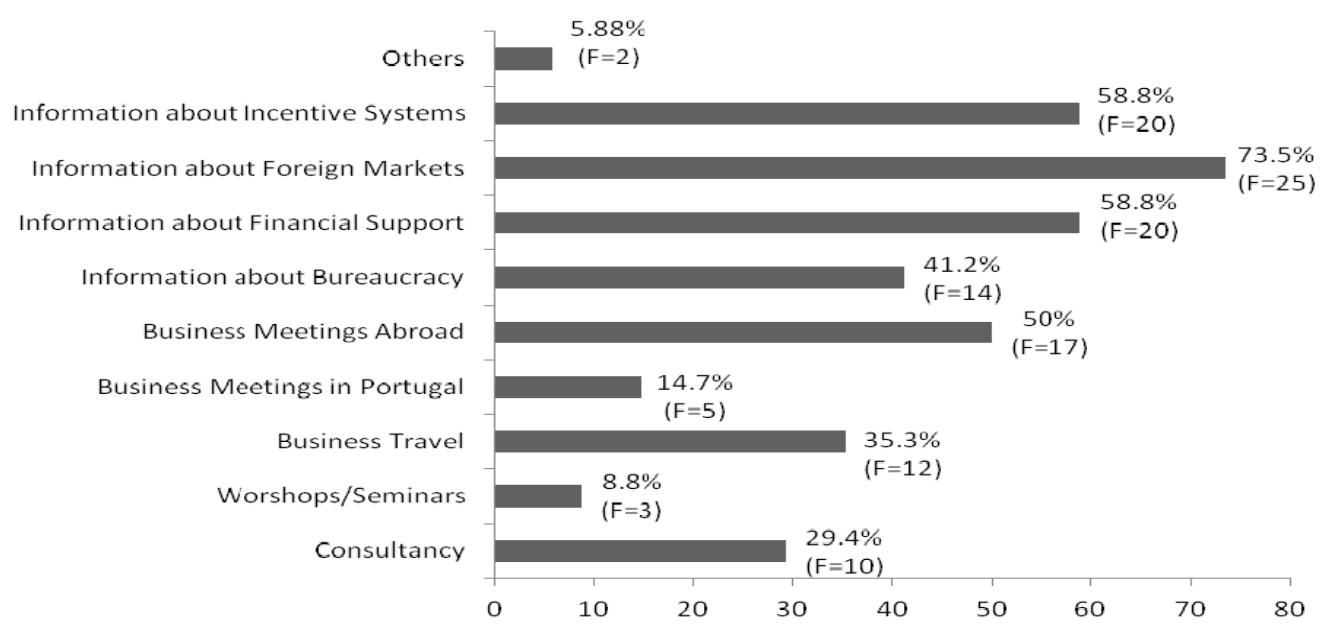

Figure 10. Ranking of supports considered as relevant (FDI).

The weakness and ineffectiveness of information networks are very likely tied to the lack of historical experience in competitive internationalization, as expressed early in this paper. At any rate, it must be concluded, more generally, that if the high importance attributed by both groups of firms to information support services it is linked to the main objective of increasing their market share, and taking into account the high proportion of SMEs among Portuguese internationalized firms, perhaps one of the models from which they can learn more, in order to improve their performance, is that of the "Born Global" case, with efficient knowledge networks at their service (Brennand \& Garvey, 2009).

\section{Governmental Support Measures for Internationalization}

In this section, the governmental measures to support the internationalization process of Portuguese firms over two periods will be enumerated and discussed. First, those that existed at the end of the 1990s are considered, and then, the measures more recently introduced. It must be pointed out that as there are no systematic evaluation studies to assess the effects of these measures, and, as a consequence, there is only some ability to evaluate them indirectly through statistical data at the macro level and from the knowledge of enterprise reality through effective exports and outward FDI.

As demonstrated in Table 2, in the 1990s, four governmental measures existed to support the internationalization of Portuguese companies. These measures were denominated "national mechanisms", as opposed to "community mechanisms" (provided by the European Union), which will not be considered in this paper. The measures basically consisted of funds that had as their target - the strengthening of the competitiveness of the economic structure and enterprise efficiency. This was mainly encouraged through incentives to acquire businesses or business shares, either in national or international contexts; to modernize and expand the existing productive structures; to start up businesses or implement new branch offices, as well as insurance schemes to support international operations. These supports were of various types and could be 
obtained through the acquisition of business shares, at most favorable interest rates, monetary grants and risk coverage of international operations according to the targeted markets and in order to diversify opportunities. ${ }^{4}$ It is worth mentioning that as time went by, the selected countries often did not become significant export destinations and that not all cases have managed to succeed in increasing the market share, which also indicates that the measures taken in this period did not produce the intended effect.

Table 2

Government Measures in the 1990s

\begin{tabular}{|l|l|}
\hline Government measure & Description \\
\hline $\begin{array}{l}\text { Portuguese Companies } \\
\text { Internationalization Fund }\end{array}$ & $\begin{array}{l}\text { Investment promoted by Portuguese companies with significant internal market share in } \\
\text { home industries with multinational growth strategies. }\end{array}$ \\
\hline $\begin{array}{l}\text { Business Restructuring and } \\
\text { Internationalization Funds }\end{array}$ & $\begin{array}{l}\text { Using FDI to increase the added value of national exports activities or to establish foreign } \\
\text { branches. Strengthening of the national economic structure competitiveness and business } \\
\text { efficiency: New business and modernization and expansion of existing productive units. }\end{array}$ \\
\hline Economic Cooperation Fund & $\begin{array}{l}\text { Special Interest Rates: In constituting start-ups or subscribing to existing ones, national or } \\
\text { abroad, or by developing branch offices, affiliates or agencies. } \\
\text { Fund incentives: Actions taken to help business and economic cooperation through the } \\
\text { preparation and promotion of economic information and training. }\end{array}$ \\
\hline $\begin{array}{l}\text { Official Support for Credit Risk } \\
\text { Coverage in Foreign Operations }\end{array}$ & $\begin{array}{l}\text { Exports credit insurance: Operations arising from exports of goods and services mostly } \\
\text { national in origin. } \\
\text { FDI insurance: Applied to capital used to create or acquire businesses or shares, or } \\
\text { developing branch offices, affiliates or agencies; repatriation or reinvestment of investment } \\
\text { profits. }\end{array}$ \\
\hline
\end{tabular}

After a certain evolution, by the end of the first decade of the 21st century, the framework for the internationalization of Portuguese firms appears relatively different from that of the 1990s. These internationalization support measures (see Table 3) are wider in scope and embrace several entities as well as more diversified forms of support. It will only be possible to judge in the future whether or not they are adequate to reach their objectives. The National Strategic Reference Framework (2007-2013) provides programs to improve the qualification and internationalization of SMEs and innovation. In addition, these systems cover measures that contribute to business competitiveness and projects that promote innovation in business plants (Júlio \& Alves, 2011, p. 57). These supports are obtained by prospecting and placing a strong presence in foreign markets by entering competitions and fairs, as well as designing international marketing material.

Regarding collaboration protocols with banks, negotiated by the AICEP, they frame the development of instruments that promote business internationalization, particularly the exports of goods and services; the stimulus to business investment and the strengthening of competitiveness as well as the image of national businesses in foreign markets. Banks themselves are committed to collaborating in relevant areas such as promoting Portugal's image and brands, and developing banking products and services that support trade and investment. These protocols are of great relevance and a great path to benefit from the synergies developed by these entities through their international departments, as well as their external market network, which can be an asset to businesses. One such case is Millennium Poland (affiliate of one of the most important Portuguese banks),

\footnotetext{
${ }^{4}$ In the realm of "national mechanisms" of support to internationalization, two lists of countries were elaborated in the 1990s: Target Markets (“Mercados Alvo”): Saudi Arabia, Iran, Algeria, Israel, Argentina, Namibia, Australia, New Zealand, Cape Verde, Czech Republic, Chile, Russia, Colombia, Thailand, United Arab Emirates, Turkey, Slovenia, Uruguay, Hungary, Venezuela, India, Zimbabwe, and Egypt, and Markets for Diversification of Opportunities (“Mercados de Diversificação de Oportunidades”): South Africa, Brazil, China, Morocco, Poland, and Tunisia.
} 
which has supported Portuguese firms develop their activity in this market.

Table 3

Government Measures Since 2000

\begin{tabular}{|l|l|}
\hline Government measure & Description \\
\hline The National Strategic Reference & $\begin{array}{l}\text { Incentives to the qualification and internationalization of small businesses: } \\
\text { Investment projects to contribute to the promotion of business competitiveness } \\
\text { through an increase in productivity, flexibility and active response and presence of } \\
\text { small businesses in the global market. } \\
\text { Innovation incentives: Investment and productive innovation projects that contribute } \\
\text { to the promotion of innovation in firms, through the production of: new goods, } \\
\text { services and processes; internationalization; technological improvement; qualified } \\
\text { entrepreneurship and structural investment in areas with large growth potential. } \\
\text { Collective Action Support: To complement incentive systems orientated towards } \\
\text { businesses, aiming to boost their results by creating or improving conditions that will } \\
\text { materialize in public goods with the objective of obtaining social gains and economic } \\
\text { drag effects. }\end{array}$ \\
\hline $\begin{array}{l}\text { Internationalization financial } \\
\text { supports-Bank collaboration protocols } \\
\text { negotiated by AICEP }\end{array}$ & $\begin{array}{l}\text { Development of initiatives and financial instruments that contribute to the growing } \\
\text { internationalization of Portuguese companies, providing special attention to export } \\
\text { growth and providing business investment to strengthen competitiveness and } \\
\text { corporate image of national companies in international markets. }\end{array}$ \\
\hline $\begin{array}{l}\text { Internationalization financial } \\
\text { supports-Credit lines: Concessions }\end{array}$ & $\begin{array}{l}\text { To deepen bilateral cooperation between Portugal and other countries through the } \\
\text { reinforcement of business partnerships in developing common interest projects. }\end{array}$ \\
\hline $\begin{array}{l}\text { Internationalization financial } \\
\text { supports-Credit lines: Commercial }\end{array}$ & $\begin{array}{l}\text { To deepen commercial relations between Portugal and other countries through the } \\
\text { strengthening of Portuguese exports to foreign markets. }\end{array}$ \\
\hline $\begin{array}{l}\text { Internationalization financial } \\
\text { supports-By sector }\end{array}$ & Supports to farming and external promotion of wines. \\
\hline $\begin{array}{l}\text { Internationalization financial } \\
\text { supports-Several instruments }\end{array}$ & $\begin{array}{l}\text { Credit insurance; Patent internationalization support line; Internationalization fiscal } \\
\text { benefits; Mutual insurance; Risk capital. }\end{array}$ \\
\hline
\end{tabular}

The support through credit lines, particularly concession credit, has the objective of strengthening and expanding the cooperation between Portugal and other countries by "reinforcing business partnerships in the development of common interest projects”, essentially targeting the exports of goods and services, as well as equipment which is essential to the development of investment projects in public infrastructures. These credits have specific lines with Morocco, Tunisia, China, Mozambique, Cape Verde, Angola, São Tomé e Príncipe and East Timor, which reveals a strong orientation towards developing Portuguese-speaking countries. Commercial credit lines are targeted to consolidate commercial ties between Portugal and Russia, Mozambique and the Dominican Republic, among which only Mozambique embraces public infrastructure projects, while all the others are exclusively for exports.

Sector supports encompass programs that promote the agriculture and wine sectors. For the former case, with more comprehensive measures, there are instruments that allow exporting countries to drain off EU products to other countries, agriculture products information and promotion campaigns (promoting the advantages of EU products) and special credit lines for farming, live stock, forest and agro-industrial (to boost the sector in order to promote competitiveness and export capacity). As an example of this orientation towards sectors, in the case of the wine industry (one of the most important exports of Portugal), the following instruments were developed: support for the promotion of wines and winery products in internal and foreign markets; in the domestic market, measures were taken to enhance the image and quality of wines, as well as advertising campaigns in public events and fairs to promote moderate wine consumption. In external markets, it was intended to increase the presence of Portuguese wines by conducting market studies, promotion events and participating in fairs and wine-driven 
events with distinctive target markets, categorized as: markets with strong potential for growth and emerging markets. This measure was developed under the guidance of the Instituto da Vinha e do Vinho (Portuguese Wine Institute).

At the same time, in this period, there are other more horizontal supports, like credit insurance, a support line to the internationalization of patents, fiscal benefits for internationalization, mutual insurance and risk capital, which target the development of international business activity while focusing on specific areas.

Also, in recent years, the government has implemented a new project focused on the proximity and support to companies that wish to export through the creation of 14 "Lojas de Exportação" (Export Shops) spread throughout the country (European Commission, 2011, p. 12). Again, it is still early to evaluate the efficiency of this project, although it has been claimed that sometimes these offices are not capable of helping the companies without the support of other entities which leads to the idea articulated earlier that a synergy between several entities should be attained. Another measure that deserves to be mentioned is the creation of the "Conselho Estratégico de Internacionalização da Economia” (Strategic Council for Internationalization of the Economy), which will be chaired by the Prime Minister; its primary mission is to promote and monitor public policies and private initiatives, and their articulation in the field of internationalization of the Portuguese economy and firms, the promotion and attraction of foreign direct investment and the development of cooperation. Again, it is still premature to judge this initiative, but, if it is borne in mind that this type of council is not an original project and that the previous similar cases did not make a significant contribution to the understanding and development of the sector. It must be recalled that the proliferation of governmental policies and measures targeting the external sector does not necessarily imply a boost to the internationalization process of firms, either by exports or FDI (inward and outward), in any sustained way.

To conclude this section, it is important to stress that despite the increase of measures supporting the internationalization of Portuguese companies, deep structural problems remain to be overcome, for which a strategic approach is needed. Credit lines and different types of support to sectors with competitive potential are not enough to meet these major challenges. More in-depth and long-term policies are necessary, for example, in order to ensure the construction of strong, competitive clusters that are responsive to major changes in the world economy, and are based on improvements of productivity and innovation. The government and other entities involved in the process must understand the extent to which the internationalization of the Portuguese economy and enterprises is late, thus lagging behind its competitors, and promote adequate measures that can substantially reduce the gap. As clearly shown by the Asian experience of the last decades, in countries that overcame their economic and technological backwardness, before any step towards deeper internationalization, they carefully enhanced their own competitiveness through comprehensive policies (Dent, 2002). On the contrary, Portugal entered into the European Monetary Union, on its inception in 1999, without a true preparation for this fundamental perspective.

For their part, firms should be prepared to confront the crude reality of the global market: tough competition, which calls for constant innovation. Companies should refrain from adopting a passive stance, using as an excuse for not internationalizing the lack of incentives, particularly financial, since such incentives by themselves will not make companies become more competitive. As correctly underlined by Porter (1990, p. 640) more than two decades ago: 
Subsidy is rarely associated with true competitive advantage... The reasons are clear... Subsidy delays adjustment and innovation rather than promoting it. Most forms of subsidy come with explicit or implicit strings attached, such as limits on where plants can be located or the number of jobs that can be eliminated. These limit flexibility and dampen innovation.

\section{Concluding Remarks}

Taking into account the poor performance of the Portuguese external sector in the last decades, as described in the beginning of this paper, after the analyses of the empirical findings of our inquiry, and focusing on the framework of measures designed to promote internationalization, it must be observed that by the end of the 1990s, the measures in place were minimal and mostly unadjusted to national reality. This can be confirmed by their reduced efficiency. Since the internationalization of firms is vital to the Portuguese economy, it must be highlighted that the essential of the measures cannot be based solely on financial support, much less on monetary grants, which lead to a lack of commitment by enterprises. The measures taken during the more recent period are broader in perspective, but at the same time better focused on specific objectives and programs, particularly at the sector level, which is believed as the most advantageous for export development (perhaps this has, to some extent, contributed to their recent upsurge, but only further research can confirm or reject such a conclusion). By developing sector programs, like those mentioned above, there is a need to carry out a proper analysis of specific products and to conduct a thorough market prospection and promotion, possibly in partnership with an association or institute which represents the sector, the AICEP and the chambers of commerce in targeted markets. The study also shows that economic diplomacy can play a greater role in the process, indeed it seems that it is already somewhat playing that role from the outward FDI perspective. Perhaps the most outstanding conclusion highlights the importance of creating an efficient and operational information network that must be put to the service of Portuguese internationalized firms (either through trade or FDI, or both) in order to eliminate the existing and persistent large gaps in the external sector.

As a first step, this study has enabled us to embark on a more systematic project concerning the performance of Portuguese firms, vis-à-vis our trading and investing partners, and in order to structurally improve the external position of the country, not only through short-term, but mainly through long-term and adaptive strategic policies. Moreover, in this research program, the firms should have a central place and their opinions, even when they are incorrect, must be taken into serious consideration. Indeed, they are determinant for the desired changes that the Portuguese economy needs to introduce in order to follow a more favorable route, particularly as far as the external domain is concerned, which is of such critical importance for the country's future.

\section{References}

Amaral, J. F. (2006). Evolução do comércio externo português de exportação (1995-2004). Lisbon: GEE Papers No. 1.

Andrade, J. S., \& Duarte, A. (2011). The fundamentals of Portuguese crisis. Panoeconomics, 2, 195-218.

Bento, V. (2010). O nó cego da economia (2nd ed.). Lisbon: Bnomics.

Bergeijk, P. A. G. van. (2009). Economic diplomacy and the geography of international trade. Cheltenham/UK: Edward Elgar, Brennan, L., \& Garvey, D. (2009). The role of knowledge in internationalization. International Business and Finance, 23, $120-133$. Dent, C. M. (2002). The foreign economic policies of Singapore, South Korea and Taiwan. Cheltenham/UK: Edward Elgar.

Dias, J. (2006). O comércio externo português e a integração europeia: alterações estruturais, conteúdo tecnológico e competitividade. In A. Romão, (Ed.). A economia portuguesa 20 anos após a adesão (pp. 519-549). Coimbra, Portugal: Edições Almedina.

Dunning, J. D. (2000). The eclectic paradigm as an envelope for economic and business theories of MNE activities. International Business Review, 9, 163-190. 
European Commission. (2011). Portugal 2010/11. SBA Fact Sheet. Brussels: Small Business Act, EU Enterprise and Industry.

Franco, M., Haase, H., Magrinho, A., \& Silva, J. R. (2011). Scanning practices and information sources: An empirical study of firm size. Journal of Enterprise Information Management, 24(3), 268-287.

Franco, M., Magrinho, A., \& Silva, J. R. (2011). Competitive intelligence: a research model tested on Portuguese firms. Business Process Management Journal, 17(2), 332-352.

GEPE (2001, March 30). A internacionalização das empresas portuguesas: Uma perspectiva genérica. Semanário Económico. Lisbon: Gabinete de Estudos e Prospectiva Económica—Ministério da Economia.

Giavazzi, F. (2010). How did the euro area get into trouble and what could be done to fix it? Global Connections, Itaú Securities, 1(3), 1-3.

Júlio, P., \& Alves, R. C. (2011). The internationalization of the Portuguese economy. Boletim Mensal da Economia Portuguesa, GEE/GPEARI, 8, 51-66.

Porter, M. E. (1990). The competitive advantage of nations. London: The MacMillan Press.

Porter, M. E. (1994). Construir as vantagens competitivas de Portugal. Lisbon: Forum para a Competitividade.

Silva, J. R. (1999). The Portuguese economy in the light of the Irish experience: A comparison of the 1990s decade. In Issues on the European economics: recent developments (pp. 221-242). Proceedings of the 3rd International Conference on European Economics. Lisbon, December 10-11: CEDIN/ISEG.

Silva, J. R. (2002). Portugal/Brasil: uma década de expansão das relações económicas, 1992-2002. Lisbon: Terramar.

Silva, J. R. (2006). O investimento directo estrangeiro. In A. Romão, (Ed.), A economia portuguesa 20 anos após a adesão (pp. 491-518), Coimbra, Portugal: Edições Almedina.

Silva, J. R. (2008). Internationalization strategies in Iberoamerica: The case of Portuguese trade. Santiago de Chile: Project Documents collection (Economic Commission for Latin America and the Caribbean-ECLAC), United Nations Publications.

Simões, C. C. (2010). Internacionalização das empresas portuguesas: processos e destinos, Master Dissertation, International Economics and European Studies. Lisbon: ISEG/UTL.

Simões, V. C., \& Cartaxo, R. M. (2011). Inward FDI in Portugal and its policy context, 2011. Columbia FDI Profiles, June 27, Vale Columbia Center.

UNCTAD. (1998). World investment report: Trends and determinants. New York and Geneva: United Nations. 